\title{
Interethnic tolerance development ways among pedagogical students at University
}

\section{Formas de desarrollo de la tolerancia interétnica entre estudiantes de pedagogía en la Universidad}

\author{
Aleksandr L. Soldatchenko \\ Nosov Magnitogorsk State Technical University, 38 Lenin Avenue, 455000, Chelyabinsk \\ Region, Magnitogorsk, Russia \\ Svetlana S. Velikanova \\ Nosov Magnitogorsk State Technical University, 38 Lenin Avenue, 455000, Chelyabinsk \\ Region, Magnitogorsk, Russia \\ Svetlana S. Rudakova \\ Nosov Magnitogorsk State Technical University, 38 Lenin Avenue, 455000, Chelyabinsk \\ Region, Magnitogorsk, Russia

\section{Svetlana V. Kharitonova} \\ Nosov Magnitogorsk State Technical University, 38 Lenin Avenue, 455000, Chelyabinsk \\ Region, Magnitogorsk, Russia

\section{Roman R. Vakhitov} \\ Nosov Magnitogorsk State Technical University, 38 Lenin Avenue, 455000, Chelyabinsk \\ Region, Magnitogorsk, Russia

\section{*Oksana P. Chernykh} \\ Moscow University of Finance and Law MFUA, 17/1 Serpukhov Val str., 115191, Moscow, \\ Russia.
}

*Correspondence

Email: cherry-100@yandex.ru
Cite as: 


\section{Summary}

The presented article is devoted to interethnic tolerance development among pedagogical students at a university.Based on the works by B. Barber, J. Berry, A.G. Asmolov, M.S. Mirimanov, V.A. Lektorsky, G.U. Soldatov and other researchers, the authors clarified the goal and objectives of interethnic tolerance development among future teachers, and also systematized its main criteria and indicators. Also, the article presents the author's complex of pedagogical conditions that ensure the development of interethnic tolerance among pedagogical students at a university. The complex includes the following components: the use of active didactic forms and interactive teaching methods in the educational process that contribute to the formation of a tolerant worldview of students; organization of interpersonal interaction of pedagogical students by their inclusion in research activities; actualization of tolerant interethnic communication experience among future teachers through the introduction of tolerance episodes into the educational process; the development of competence among pedagogical students in the field of interethnic tolerance development among schoolchildren during the educational process.

are reported.

Keywords: tolerance, interethnic tolerance, pedagogical students.

\section{Resumen}

El artículo presentado está dedicado al desarrollo de la tolerancia interétnica entre estudiantes de pedagogía de una universidad. Basado en los trabajos de B. Barber, J. Berry, A.G. Asmolov, M.S. Mirimanov, V.A. Lektorsky, G.U. Soldatov y otros investigadores, los autores aclararon la meta y los objetivos del desarrollo de la tolerancia interétnica entre los futuros profesores, y también sistematizaron sus principales criterios e indicadores. Además, el artículo presenta el complejo de condiciones pedagógicas del autor que aseguran el desarrollo de la tolerancia interétnica entre los estudiantes de pedagogía de una universidad. El complejo incluye los siguientes componentes: el uso de formas didácticas activas y métodos de enseñanza interactivos en el proceso educativo que contribuyan a la formación de una cosmovisión tolerante de los estudiantes; organización de la interacción interpersonal de los estudiantes de pedagogía mediante su inclusión en actividades de investigación; actualización de la experiencia de comunicación interétnica tolerante entre futuros profesores a través de la introducción de episodios de tolerancia en el proceso educativo; el desarrollo de la competencia entre los estudiantes de pedagogía en el campo del desarrollo de la tolerancia interétnica entre los escolares durante el proceso educativo.

Palabras clave: tolerancia, tolerancia interétnica, estudiantes pedagógicos.

\section{Introduction}

\section{Introduction to the problem}

Consideration of interethnic tolerance development problem among the younger generation is determined by the need of modern society for social and spiritual progress, stability and intolerance prevention.

A special place in this process is given to educational institutions as a social institution that has a direct impact on a child's personality development. However, in the conditions of traditional education, the development of interethnic tolerance among students is spontaneous and ineffective. Therefore, special work is needed to train future teachers in methods, techniques and means of schoolchild tolerance development, which will allow to form the competence of life in a multicultural society for the younger generation, the skills of independent thinking, the ability to resolve conflicts in a non-violent way, develop the ability to respect each other, live with people of other cultures, languages and religions. 
In our opinion, the development of interethnic tolerance among pedagogical students can become the basis for the spiritual and moral development of civil society.

\section{Problem relevance}

The urgency of interethnic tolerance development problem among pedagogical students is determined by the following factors:

1. At present, globalization and the growth of migration processes have led to the growth of ethnocultural contradictions and the intensification of ethnic conflicts, which has caused an increased interest in the issues of tolerance and interethnic interaction on the part of representatives of various fields of knowledge, including philosophers, historians, psychologists and teachers.

2. Russia has historically been formed as a multinational state, which at one time included dozens of peoples. Therefore, it is essential to search for a system of measures to overcome ethnic prejudices, prevent ethnic conflicts and combat xenophobia for all ethnic groups and for individual citizens in our country.

3. Modern society is interested in tolerant consciousness development among young people. However, the organization of this process in educational institutions has not been studied sufficiently in theoretical and practical terms.

In this regard, the importance of interethnic tolerance development among pedagogical students and their preparation for practical work in multi-ethnic classes increases. The training of future teachers should include the development of skills to resolve conflicts in a multinational team, foster the culture of interethnic communication among schoolchildren and prevent their intolerant attitude towards other ethnic groups.

\section{Problem study}

The analysis of theoretical sources shows that the problem of interethnic tolerance formation and development has a long history and originated in the era of antiquity. For the first time the concept of tolerance appeared in the 16-17 centuries during the period of religious wars in Europe. Erasmus of Rotterdam was one of the first to substantiate the principle of tolerance. The works by Voltaire, J. Locke, M. Montaigne, F. Bacon and other figures of the Enlightenment were devoted to the study of tolerance problem.

The ideas of tolerance run through the whole Russian humanistic philosophy (V. Soloviev, N. Berdyaev, V. Rozanov, P. Florensky). The model of "a person who understands" arose in the experience of Russian culture of the 19th century (F.M. Dostoevsky, L.N. Tolstoy) based on the idea of a dialogue between interacting subjects, their mutual enrichment and complementarity with each other's experience. The most active study of the phenomenon of tolerance, including interethnic, begins during the second half of the 20th century. The problems of interethnic tolerance in a multicultural society are being developed by the scientists from different countries. B. Barber, J. Berry, G. Main, M. Walzer and others are among them. Russian developments are presented in the works by A.G. Asmolov and M.S. Mirimanov, in which the psychological aspect of this phenomenon is studied, V.A. Lektorsky, who considers interethnic tolerance as a value, and V.V. Shalin, who defines it as a political necessity. A.O. Vyzov considers tolerance as a tool for interethnic conflict resolution, E.A. Kleptsov and G.U. Soldatov consider it as a personality trait, D.V. Zinoviev and V.S. Nurgaleev - as a moral value.

The problem of interethnic tolerance development in the educational process of a general education school has been studied by domestic psychological and pedagogical science in various aspects: the role of the humanitarian discipline in the formation of tolerance (V.A.Lektorsky, A.V. Nikolsky, A.I. Repinetsky); general issues of tolerance psychology and pedagogy (I.V. Abagumova, V.V. Glebkin, P.N. Ermakov, M.S. Mirimanova, A.A. Pogodina, M.I. Rozhkov, G.U. Soldatova, L.A. Shaigerova, O.D.Sharova and others); ethnic tolerance (G.G. Abdulkarimov, Z.T. Hasanov, G.M. Gogeberidze, V.S.Kukushin, G.V. Palatkina and others). At the moment, there are the studies on the problems of tolerance development (A.M.Baibakov, N.P. 
Edygova, I.V. Krutova, P.V. Stepanov, G.M. Shelamova), considering this process in the context of a comprehensive school.

However, despite an extensive analysis of interethnic tolerance phenomenon in the scientific literature, its practical aspects are poorly developed, and therefore the problem of interethnic tolerance development among future teachers of higher education remains unsolved. The noted circumstance led to the choice of the article topic.

\section{Hypothesis}

The effectiveness of interethnic tolerance development among pedagogical students is ensured by the implementation of the following set of pedagogical conditions:

1. Application of active didactic forms and interactive teaching methods in the educational process that contribute to the formation of a tolerant worldview among students;

2. Organization of interpersonal interaction among pedagogical students by their inclusion in research activities;

3. Actualization of tolerant interethnic communication experience among future teachers through the introduction of tolerance episodes into the educational process;

4. Development of competence among pedagogical students in the field of interethnic tolerance development among schoolchildren during the educational process.

\section{Methods}

To solve the set tasks, we used a set of theoretical and empirical research methods: theoretical and comparative analysis of the literature on the research problem, analysis of the regulatory framework for the activities of secondary and higher education institutions, targeted pedagogical observation, questionnaires, testing of pupils, students and teachers, modeling of social pedagogical situations in the educational process; generalization of experimental data, analytical and mathematical processing.

\section{Main part}

Addressing the problem of university student interethnic tolerance development, we proceeded from the following provisions:

- Tolerant behavior is one of the highest human values both for an individual person and for society as a whole;

- Tolerance is the initial condition that ensures moral comfort of an individual, and successful adaptation, on the one hand, and it is the main condition for social progress on the other hand;

- Development of tolerance among the younger generation is the most important strategic task of modern education.

The path to interethnic tolerance is a serious emotional, intellectual work and mental stress, because it is possible only on the basis of changing oneself, one's stereotypes, and one's consciousness.

The goal of interethnic tolerance development among the younger generation is to develop the need and readiness for constructive interaction with people and groups of people, regardless of their nationalities, social, religious affiliation, views, worldview, styles of thinking and behavior.

This goal is possible to achieve when they solve specific tasks, which can be combined into two interrelated blocks:

1. Development of peacefulness in schoolchildren, acceptance and understanding of other people, the ability to interact with them positively (through the formation of a negative attitude towards violence and the development of respect for oneself and for other people).

2. Creation of a tolerant environment in society and in the field of education (through the inclusion of the leading ideas of pedagogy of tolerance in the reform of education and via 
reforming the system of future teacher training to foster interethnic tolerance in children and adolescents).

Considering that interethnic tolerance is not only an active moral position, but also psychological readiness for tolerance to interact with people of different culture or social environment positively, we systematize its main criteria and indicators:

1. The criterion "Personality stability" (formation of social and moral motives of personality behavior in the process of interaction with people of other ethnic or social communities) is determined by the following indicators: emotional stability; benevolence, patience; social responsibility; and independence.

2. The criterion "Empathy" (an adequate idea of what is happening in the inner world of another person) is realized through empathy and the ability to reflect.

3. The criterion "Divergence of thinking" (the ability to solve problems in an unusual way, to look for several solutions) is characterized by the absence of stereotypes and prejudices; flexibility and critical thinking.

4. The criterion "Mobility of behavior" (the ability to change strategy or tactics quickly, taking into account the prevailing circumstances) is manifested through the absence of anxiety, sociability and autonomy of behavior.

5. The criterion "Social activity" (readiness to interact in various social interethnic situations in order to achieve the set goals and build constructive relations in society) is determined through social self-identification and social adaptation.

Based on these criteria, we identified a set of pedagogical conditions that ensure the development of interethnic tolerance among pedagogical students in a university.

The complex of pedagogical conditions includes the following components:

1. Application of active didactic forms and interactive teaching methods in the educational process that contribute to a student tolerant worldview development. This pedagogical condition was implemented by us in practice through the following types of educational work:

- Application of situational analysis methods, contributing to the student humanistic value system development, the development of their thinking flexibility and a positive attitude towards their individual characteristics. Future teachers were offered the classroom situations that contribute to the development of communication skills (trainings, discussions, role-playing games, round tables, collective planning, etc.); the development of responsibility and ability to make decisions (business games, work in micro groups, individual and group research, etc.); as well as the situations of success (contests, intellectual competitions, tournaments).

- Involvement of future teachers in dialogical communication aimed at student empathy and reflection development, which made it possible to establish emotional and trusting relationships with them, maintain and, if necessary, correct the process of value self-determination and student development.

- Conduct of special trainings aimed at the formation of interethnic tolerance among students, based on understanding, cooperation and the spirit of partnership. The trainings developed by the team of authors were aimed at the development (among pedagogical students) of such types of tolerance as the tolerance towards representatives of other nations and cultures; the tolerance to other views and opinions; the tolerance to the complexity and uncertainty of the surrounding world; the tolerance towards oneself. It should be noted that the greatest interest among future teachers was caused by such training methods as the method of motivation to assess someone else's position and its interpretation; demonstration of personal experience techniques and the method of the interlocutor's position virtual display. The application of the above methods and techniques made it possible to form students' internal motives for tolerant behavior, teach them to regulate their emotional state and take into account other points of view, as well as to realize the importance of tolerant behavior models.

2. Organization of interpersonal interaction among pedagogical students by their inclusion in research activities. The process of research activities involves a joint creative search of students based on a dialogue. A sociological survey, the interviews with witnesses of historical events, acquaintance with folk pedagogy and national folklore in the field of education of the younger generation, conversations with specialists, excursions allow future teachers to get into cultural, religious and ethnic traditions that are unfamiliar to them, where there are other features of 
communication and life style. The result of the students' work was not only the presentation of research activity product at scientific conferences, readings and competitive intellectual events of various levels, but also the awareness by the students of the need to develop interethnic tolerance. 3. Actualization of tolerant interethnic communication experience among future teachers through the introduction of tolerance episodes in the educational process. The meaning of tolerance episode creation is philosophical and pedagogical: substantiation of reflexive activity, research methods of value knowledge provision and teaching peacefulness. An example of tolerance episodes can be the periodic inclusion of brief information about folk pedagogy, the specifics of some religious requirements, biographies of famous teachers, etc. in the studied theoretical material. The introduction of tolerance episodes presupposes the purposeful creation of conditions for the development of tolerance for dissent, the ability to understand another, awareness of one's own behavior norms, and resistance to interethnic conflicts.

4. Formation of competence among pedagogical students in the field of interethnic tolerance development among schoolchildren during the educational process. The main directions of our work on the implementation of this pedagogical condition were to familiarize future teachers with theoretical ideas about interethnic tolerance, its role and place in the system of universal human values, as well as about the development of skills and abilities of interethnic tolerance among the schoolchildren on the basis of teaching and educational tools, methods and techniques. The effectiveness of the developed complex of pedagogical conditions, ensuring the development of interethnic tolerance of future teachers, was confirmed as a result of the experimental work carried out during 2015-2020. The experiment involved 150 pedagogical students of 1 - 5 courses.

\section{Conclusions}

In the course of the experimental work carried out, we obtained the following results:

1. The content of the concept "interethnic tolerance" has been clarified and its criteria and indicators have been systematized.

2. A complex of pedagogical conditions has been developed and experimentally tested, ensuring the development of interethnic tolerance among the students of pedagogical specialties.

3. They selected, systematized and tested the methods that allow teachers to develop interethnic tolerance of students during the educational process.

4. Research of such personal qualities of pedagogical students as criticality and flexibility of thinking, resistance to uncertainty, as well as determination of their interethnic tolerance level development on the basis of the questionnaire we have developed, showed that if the formation of interethnic tolerance of students is not pursued purposefully, then it occurs spontaneously and cannot be sufficient (most of the future teachers have a low and medium level of interethnic tolerance development). In the experimental groups, the indicators of the of interethnic tolerance development among the students of pedagogical specialties increased by $26 \%$ on the average.

All of the above allows us to conclude that this hypothesis is confirmed. This study does not exhaust the entirety of the problem considered. Its further development can be continued in the direction of search for new means of interethnic tolerance development among the students of pedagogical specialties, both in the educational process of the university and in extracurricular activities.

\section{References}

Shtanski, N. (2009). foRmATIoN of A "NEw" PoST-SoVIET IdENTITy AmIdST EThNoPoLITICAL CoNfLICT: ThE CASE of TRANSdNIESTRIA. MoldovATrAnSdnieSTriA: Working Together for, 210.

Asmolov, A. G. (2013). Strategy and methodology for the sociocultural reform of education. Psychology in Russia: State of the art, 6(1).

Bardier G.L. (2005).Social psychology of tolerance. SPb.: Publishing house of S.-Petersburg University, $120 \mathrm{p}$.

Bakholskaya N.A.(2017). The influence of interactive learning on the development of pedagogical student professional orientation at a university // Humanitarian and pedagogical 
research. - Magnitogorsk: Magnitogorsk Publishing House. State tech. un-ty nabed after G.I. Nosov, V. 1. No. 1. pp. 45-49. [in Russian].

Bourdieu, P. (2001). Prakticheskii smysl [Le Sens pratique/Practical reason]/transl. from French by AT Bikbov, KD Voznesenskaia, SN Zenkin and NA Shmatko; ed. and afterword by NA Shmatko. St. Petersburg: Aleteiia Publ. 562 p.

Chelysheva, I., \& Mikhaleva, G. Copyright $\odot 2020$ by Academic Publishing House Researcher sro Published in the Slovak Republic.

Bakholskaya, N. A., Nazarova, O. L., Velikanova, S. S., Zharova, K. E., Igoshina, N. V., \& Chernykh, O. P. (2019). Inter-ethnic tolerance and its development among pedagogical students of higher educational institutions. Amazonia Investiga, 8(18), 359-365.

Morozov, V. (2008). Sovereignty and democracy in contemporary Russia: a modern subject faces the post-modern world. Journal of International Relations and Development, 11(2), 152-180.

Pocheboot L.G.(2005). Study of mutual understanding of cultures. Methodology and methods of ethnic and cross-cultural psychology. Psychology of interethnic tolerance. St. Petersburg Publishing House of St. Petersburg University, p. 69.

Tolerance in modern civilization / Collection of teaching materials2007, developments. M.B. Khomyakov, I. G. Polyakova, Yekaterinburg,

Mitcham, C., \& Mackey, R. (1973). Bibliography of the Philosophy of Technology. Technology and Culture, 14(2), v.

Philosophers of Russia of the XIX-XX-th centuries. 1995. Biographies, ideas, works. - M.: "Book and Business", pp. 552-555.

Berry, J. W., \& Kalin, R. (1995). Multicultural and ethnic attitudes in Canada: An overview of the 1991 national survey. Canadian Journal of Behavioural Science/Revue canadienne des sciences du comportement, 27(3), 301.

Campbell, D. T. (1967). Stereotypes and the perception of group differences. American psychologist, 22(10), 817.

King, P. (1971). The problem of tolerance. Government and opposition, 6(2), 172-207.

Nazarova, O. L., Rudakova, S. V., Akasheva, T. V., Velikanova, S. S., Bakholskaia, A. A., \& Chernykh, O. P. (2019). THE DEVELOPMENT OF COMMUNICATIVE COMPETENCE OF UNIVERSITY STUDENTS IN THE PROCESS OF THEIR PROFESSIONAL TRAINING. REVISTA PRAXIS EDUCACIONAL, 15(36), 599-609.

Nazarova, O. L., Soldatchenko, A. L., Rudakova, S. V. (2018). Implementing the continuousand-synergetic approach to social maturity formation in college students. Perspektivy nauki i obrazovania - Perspectives of Science and Education, 36 (6), 36-47. doi: 10.32744/ pse.2018.6.4. (In Russian).

Soldatchenko A.L., Baklykova T.Yu., Kharitonova S.V., Rudakova S.V., Velikanova S.S., Chernykh O.P(2020).. Influence of an interactive learning model the professional competence of university students // International Journal of Innovation, Creativity and Change. Vol. 12. № 2. pp. 583-590.

Soldatchenko A. L., Kostyuchenko M. V.(2017)., Formation of university students' value orientations as a basis of their social self-determination // Libri Magistri. №4. Pp. 133-138 (In Russian).

Volkova V.B., Kozko N.A., Pitko O.A., Postnikova E.G., Tsurkan V.V., Abramzon T.E., Rudakova S.V.(2018). The Russians view of Bashkir culture as predominantly traditionalistic one // Modern Journal of Language Teaching Methods. V. 8. № 3. pp. 317-325. 